25. A.S. Akhiezer. Rossiya: kritika istoricheskogo opyta (Sotsiokul'turnaya dinamika Rossii) [Russia: critique of historical experience (socio and cultural dynamics of Russia)]. Theory and methodology. Dictionary. Vol. 2. Siberian chronograph, Novosibirsk (1998), 594 p.

26. A. P. Davydov. Problema mediatsii v yevropeyskoy kul'ture: Zapad i Rossiya [The problem of mediation in European culture: The West and Russia]. Obshchestvennyye nauki i sovremennost', No. 6 (2000), pp. 82-93.

27. A. A. Pelipenko. Kontrevolyutsiya [Counter-evolution]. Publishing House “Znaniye", Moscow (2016).

28. G. Rikkert. Nauki o prirode i nauki o kul'ture [Science about nature and Sciences about culture]. Kul'turologiya XX vek: Antologiya [Cultural studies of the XX century: an anthology], Yurist, Moscow (1995).

DOI 10.15826/B978-5-7996-3081-2.23

\title{
Language Diversity in Business Communication in the Social Network Instagram (On the Example of Bars, Cafes and Restaurants Ads)
}

\author{
Gudova Margarita', Litwinova Anastasia \\ 1 Ural Federal University, Ekaterinburg, Russia \\ ${ }^{2}$ Ural Federal University, Ekaterinburg, Russia \\ Corresponding author: Gudova Margarita, MargGoodova@gmail.com
}

\begin{abstract}
The research subject of this article is the language diversity of the European restaurant business. The methodology is defined by the understanding of polylinguism as the diversity of languages used in the same text, where each of the languages performs its own communicative functions. The study was performed using the Case Studies method, due to which the author managed to review a certain amount of cafes, bars and restaurants via the social network Instagram made over the past year, analyze the use of different languages, and draw a conclusion about the pragmatic aspects of their use.
\end{abstract}

Keywords: Instagram, language diversity, polylinguism, social network 


\section{Introduction}

Means of Internet communication are transforming and being modified every day. Social networks are playing an increasingly important role in everyday and business communications. The Internet allows communication between users who speak different languages of verbal and non-verbal communication, and represent the cultures of distant countries and continents [Zuckerman 2015]. Since various network trends and social networks are gaining and losing popularity in a one moment, it is important to highlight the contemporary features of communication in the Instagram network.

Today having an account on the Internet is a necessary factor for development of any business. It allows responding to customer requests in a real time, regardless of the company or client's location, providing the most relevant information. Representation in social networks is a special and very important thing for business-to-consumer companies, because it forms their reputation capital. As K. Schwab writes in his book - "The fourth industrial revolution" -: "maintaining contact, interaction, feedback, transparency — all this forms the basis for a trust relationship between a business and its client" [Schwab 2020].

Cafe and restaurant blogs are very common on Instagram. The platform allows them to post the restaurant's interior, dishes, cooking process or staff photos. The text part of publications is also important, because there the name of the dish and its features are told, promotions are announced, the working hours are published or the staff could be introduced, and so on. This creates a welcoming image of a place and the accounts of such places can be maintained either by employees themselves or by content managers.

International tourism, as well as the official multilingualism in some countries, opens up the possibility of using multiple languages in blogs.

\section{The main purpose of the study}

The purpose of the research is to analyze the multilingual segment of the blogs and identify the social and communicative functions of the languages. To do this, the author will investigate how languages co-exist in the blog, for what purpose each of them can be used, and how the image of the place is created by using a multilingual tool. The author aims to define a set of linguistic resources used in the blog so as to create the image and reputation of a food service place. 


\section{Methodology}

In this study qualitative research methods were used. For these methods, it is necessary to collect and analyze all types of data that are informative [The Blackwell Guide 2008, 43]. For this work, such data is text publications in blogs. For a qualitative research method, the context is the determining factor, but the experience of the test sample is considered entirely. It should be remembered that this approach is characterized not only by understanding the experience from the point of view of the author and readers, but also by adopting a theoretical framework that provides an explanation of localized practices in a broader context.

In addition, in a qualitative method, it is preferable to study open longterm practices of language selection. Therefore, this method is the most appropriate for this work.

Since it is impossible to identify the total number of food service blogs for the research, a non-random estimated (target) sample was used. The selection of blogs is based on the observation of these blogs in order to study the most representative samples.

The style and methods of blogging for each institution, although they may have some common trends, are very different, so it makes sense to conduct a more individualized analysis of each blog. At the same time, the highlighting of above-mentioned common trends is also important, because it allows the author to consider them fully, and at the same time, to study in detail the various unique situations of multilingualism. Taking into account these factors, the chosen qualitative research method and the importance of data interpretation, one of the best research methods will be the case study method.

By creating a case study, the author will be able to study the data deeply. However, some limitations of this method, such as the impossibility of statistical analysis and generalization of conclusions should be noted, as well as the probability of bias.

In theoretical terms, the author will focus on the principles of using language resources, considering semantic, value features and aspects of the language in the context of publications. Such aspects as authenticity, practicality, stereotyping, connection with the cultural background, internationality, creativity, recognizability, identity will be investigated.

For the study were selected all publications dated 2019 in the selected blogs. Hashtags were not considered, except when they are located inside the main text. The author did not analyze aspects of the language in the blog 
if it is the state language (for the country where the institution is located) and is present in at least half of the blog posts.

\section{The body of the research}

\subsection{Case study No1 "CiPiaCe - @cipiacebar"}

The case analysis focuses on the Instagram account [CiPiaCe].

Located in Belgium, the cocktail bar of Italian cuisine @cipiacebar called "CiPiaCe" (which could be translated as 'we like it'). It should be mentioned that the official languages of Belgium are Dutch, French and German. The Italian phrase in the name already implies some prior knowledge of customers who are interested in Italian cuisine, and therefore, in some ways, are familiar with the culture and the language of Italy.

In 2019, 167 posts were published, 143 of which were in English, 20 publications used English and Italian, 3 - only Italian, and the one - English and French.

Most of the publications are written exclusively in English. In my opinion, this is because English is the official language of the European Union. Based on this, we can conclude that English is the "main" language of communication with the clients for this bar, and the main information about the place is transmitted in this language. Extensive use of English also makes the blog content more comprehensible to potential visitors [Kozlova, 2020].

French is used only once in a year of regular publications and only in the context of location designation in a post dated May 13, 2019: "The sun is back on parvis de Saint Gilles" ("The sun has returned to Parvis de Saint Gilles'). Parvis de Saint Gilles is a place near a bus stop named the same. To understand this publication, knowledge of grammatical structures and vocabulary of the French language is not required. It is only necessary to recognize the French language in the context of English. When you look at the text publication together with the visual part, it becomes clear that we are talking about a specific point on the map of Brussels.

Therefore, the French language here has only a practical aspect, it marks the location of the bar, the address, it does not transmit cultural values, it does not affect the bar image formation.

In this case study, the posts where the Italian and English languages appear are the most interesting. Posts in which a description of the dish is given in Italian, but no transcript or translation into English is provided. In total, I find only 10 such publications dated 2019. 
Let's look at an example of one of the publications containing Italian and English. Caption for September 24, 2019: Discover our new menu in Antwerp : Tagliolini con acciughe, stracciatella, limone e mollica di pane fritto. ('Discover our new menu in Antwerp: tagliatelle pasta with anchovies, stracciatella ice cream [approx.: vanilla ice cream with chocolate chips], lemon and fried breadcrumbs).

A potential client, who is looking for an Italian cuisine cafe, seeing such a post, will understand that the publication uses the Italian language. It can be assumed that a connoisseur of Italian gastronomy has a partial initial knowledge of grammar and a thematic vocabulary, which will allow him not only to evaluate the use of Italian, but also to understand better the meaning of the publication.

Thus, in this case, the authenticity is most acute: the Italian dish is described in Italian; as well as the value position, which is manifested in the fact that no explanation is given in English. They are trying to say that Italian food is so great by itself, that its image should not be vilified by translation into another language.

Furthermore, the authenticity aspect is expressed by the fact that the proper names of dishes, drinks, and ingredients (culture-specific words) are not explained: parmigiana (an eggplant dish), negroni (an alcoholic cocktail), caciocavallo and burrata (types of cheese), pancetta (a type of bacon), paccheri (a type of pasta), bruschetta (a type of snack), etc. Each of these names contains the appearance, serving, and ingredients nuances, which in some cases can be reflected on the photo. Some terms used may be more common and commonly used in culture, such as parmigiana, burrata. Others are less well-known. The explanation of such pecularities in the text can be quite long. Anyone who has never tasted such a dish will be intrigued, and a knowledgeable person already knows, what is hidden behind these words, and thus it is reasonable to omit these explanations.

In the publication that tells about the bar staff and chefs, we can also see an aspect of authenticity associated not only with the names of dishes, but also with the names of regions - a post dated March 23, 2019: "<...>Arianna and Vincenzo are partner in the Kitchen but also in life, and just like Andrea and Giorgia, they also come from Puglia. Come and try their amazing soul food, full of love". The aspect of authenticity is expressed in the fact that the name of the region of Italy - Apulia is given as Puglia, although the generally ac- 
cepted English version is - the Apulia. The choice of using the Italian version is a small detail, but this element forms the image of a "true" Italian bar.

There are also elements of the language game, for example, the post dated March 6, 2019: "Cipiace L'Aperitivo: We are very excited to invite you to our first CiPiace Antwerp aperitivo of a long series <...>”. Approximate translation: 'an Aperitif at Cipiace: we are very happy to invite you to our first aperitif at the CiPiaCe bar in Antwerp'.

First of all, it should be noted that the aperitivo, in English looks like an aperitif, but it is assumed that the reader will be able to relate the aperitif to the aperitivo by analogy.

The phrase Cipiace l'aperitivo can be considered and translated from the point of view of a person who does not have competence in Italian as 'an Aperitif in Cipiace' (Cipiace is the name of the bar). However, if you take into account the presence of a minimal competence in Italian, you can also see the wordplay: "Ci piace l'aperitivo" could be translated as "we like an aperitif".

This form of language creativity allows one to interact both with those who do not have knowledge of Italian, and with those who have a little. The similarity of English aperitif to Italian aperitivo also opens up the possibility of forming an initial vocabulary for those who have never interacted with the Italian language.

This word was also found in other publications, for example, in the post dated May 23, 2019, where there is the phrase see you tonight for l'aperitivo. The reader is invited to a light language game that allows them to immerse themselves into the Italian culture.

In both cases, the Italian language is hinted at not only by turning aperitif into aperitivo, but also by adding an apostrophized definite article before it, which increases the immersion in the language game. It is also important to note the issue of phonetic, grammatical and morphological stereotypes of the Italian language, and how the Italian language is portrayed in popular culture. With a few details, you can create an image of a phrase that will be perceived as "Italian". Therefore, here we see a vivid example of using the aspect of stereotyping, which may not be too exaggerated and grotesque, but clearly indicate the properties of a particular language.

Several posts use Ragazze \& ragazzi and Ragazzi as an appeal to readers, instead of the more typical Guys, which is expected to be used in such cases. Ragazzi is a common Italian friendly address to both friends and strangers, it is not official, and does not apply to people who are significantly older in age. 
Ragazzi in this case represent an aspect of cultural value rather than stereotypes. It is believed that Italians are distinguished by openness and cordiality, which are reflected in this appeal to their visitors.

There are also phrases Grazie 'thank you', Prego 'please', Ciao 'hi/bye'. Grazie and Ciao can be met at the end of the English text, representing small symbols of Italian culture and expressing authenticity.

It is interesting to take a closer look at the example of using Prego. The text part of the publication has only a single word, but the photo undoubtedly helps to add context to the phrase and provides a hint for the reader who does not speak Italian. The situation played: the bartender puts a cocktail on the counter in front of the customer and tells him: "Prego!" ('Please, [here is your order]'). In addition to authenticity, we see here a vivid example of forming the image of an institution as being truly Italian.

Another publication worth mentioning is the post dated December 22, 2019 "Buon Natale! We will be closed from tomorrow December 23rd until the 26th [...]" We can see that Buon Natale is not changed by Merry Christmas, but by focusing on the date of publication, the reader can recognize this phrase in Italian and understand what it means.

From all of the above, we can conclude that the reader, a potential visitor is expected to have a fairly high education attainment. The blog of this bar serves as a guide not only to the bar life itself, but also to the culture of Italy. For a regular guest or someone who already understands Italian traditions and cuisine, "inserts" of Italian words, phrases and sentences are a distinctive sign, reminding them that this place will help them immerse themselves in the Italian atmosphere.

The names of dishes refer to precedent texts, which means that some names may be more recognizable. However, this institution aims to cover Italian cuisine more widely, beyond the most common and stereotypical dishes. This is also reflected in the way the blog the author use Italian: in those publications where the dish is described in Italian without translation or explanation in English.

We can conclude that even infrequent, small inclusions of the Italian language in publications form the image of this institution: authentic terms for dishes and ingredients help to increase the credibility of the bar. They qualify it, confirm the fact that the dishes and drinks that are prepared in the bar really belong to Italian cuisine. Thus, using the example of this blog, we considered the manifestation of such polylingual functions as authenticity, values, internationality, creativity, and identity. 


\subsection{Case study No2 "MOLÁM Thai Canteen \& Bar — @molam_krk"}

The case analysis dwells upon the Instagram account [MOLÁM Thai Canteen \& Bar].

The following case is the blog @molam_krk. This is the account of Molam Thai restaurant and bar located in Krakow, Poland. In 2019, the the author published 88 posts that actively and regularly use English and Polish, as well as Thai and French. Despite the fact that the bar is located in Poland, were found only three posts that were written exclusively in Polish, without using elements of any other language, dated the year of 2019. There are also only three publications for 2019 without using Polish, so this case does not analyze aspects of using the Polish language.

Let's analyze the post dated June 20, 2019, which contains Polish, English and French:

“Proces 'menu development' często bywa zaskakujacy i tak tez było $w$ tym przypadku. Poszukując nowego dania w którym Pak chi lao (koperek) i nahm prik pao (chilli jam) świetnie by razem zagrały wpadliśmy na szalony pomyst aby połaczyć je z naszym rodzimym starokleparskim bobem... i to byt, moi drodzy, totalny strzał $w$ dziesiatkę!

Powstało 'małżeństwo idealne' - poznajcie wiec Thaw Pak Xa $z$ Nahm Prik Pao \& Pak Chi Lao czyli Bób z koperkiem \& chilli jam. Joie de vivre!!"

("The process of "menu development" is often full of surprises, as it was in this case. In search of a new dish where Pak chi lao (dill) and nahm prik pao (chili jam) would play great together, we came up with the crazy idea of combining it with beans... and it was, my dears, just a bull's-eye!

The "perfect marriage" was born, so meet Thaw Pak Xa with Nahm Prik Pao and Pak Chi Lao or beans with dill and chili jam. The joy of life!!')

As we can see, in this publication, Polish is the main language that conveys not only the actual information about the institution, but also the emotions caused by the process of creating dishes.

Highlighting the phrase 'menu development' in English may indicate the stereotypes of internationality of a Business English, which demonstrates the professionalism of this process. The phrase menu development creates a contrast with the rest of the text, because in general the publication enthusiastically talks about culinary discoveries.

We also see a small manifestation of English in the phrase chilli jam, which is found not only in this entry, but also in the subsequent "Polish" part of the text. The phrase could be translated as 'dżem z papryczki chili', but 
the the author preferred the English version. This choice can be explained by the practicality and brevity of this variant, as well as the high degree of recognition of the word jam, even for the Polish reader

The delight of discovering a new combination of ingredients is conveyed, among other things, by the sentence in French - Joie de vivre. This is a very common phrase, widely used among English-speaking people, conveying a state of admiration and enjoyment. Here we can talk about a pronounced aspect of recognition, taking into account the popularity of the phrase.

Thai is used here (and, as we will see later, in all other blog posts) to refer to dishes and ingredients. In this publication, we observe the writing of the Thai language in the Latin alphabet, which facilitates the process of recognizing lexemes for a reader who does not speak this language. It should also be noted that the the author do not expect to know this language and kindly explain that pak chi lao is a dill, and nahm prik pao is a chili jam. Then the name of the new dish is announced: Thaw Pak Xa, which contains a combination of these ingredients.

The process of designation and explanation in this case resembles an educational process. A potential guest is not expected to know the Thai language or culture, and we can objectively note the fact that the restaurant takes on the role of educator. At the same time, the direct use of the Thai language reflects the authenticity and professionalism of the institution, as it demonstrates a high level of involvement in their business.

It is fair to say that a Thai cuisine lover has some passive vocabulary related to the names of dishes and ingredients.

Many ingredients and dishes of Thai cuisine do not have widespread analogues in European cuisine, so the use of the Thai language has several aspects: practicality (for more precise indication of certain types of products) and authenticity (the "true" name of products). This creates an image of the restaurant and staff as experts in their field, with original knowledge of the cuisine they offer.

Next, let's pay attention to the post dated June 22, 2019, which describes the production of wine: "<...>W ten weekend, $w$ Krakowie będziecie mogli spróbowac pierwszych kieliszków \#’'18 tylko@molam_krk.

@dombliskowice Chapeau bas! We owe you one!

@pbrocki thanks for your support!!" ('This weekend in Krakow, only in Molam, you can try the first glasses J'18. @dombliskowice [note: winery account] hats off! We owe you one. @pbrocki thanks for your support!!'). 
In this publication, we observe multilingual interaction using various language resources. In this case, English and French are used at the level of minimum competencies related to the knowledge of common phrases.

The expression chapeau bas has been localized in many languages, for example, 'hats off' in English. The decision to use this expression in French may be due to the fact that the author wanted to reflect on the level of French culture the manifestation of the mastership France is associated with good manners, upbringing and etiquette, so words of respect expressed in its language emphasize the message. In addition to the recognition aspect, there is also the value aspect attributed to culture.

The stable expression I owe you one is contained in the Cambridge online dictionary and implies gratitude for what has been done, and also contains an indication of help in return. Most likely, the aspect contained in this case is related solely to the recognition and anchoring of this phrase in the language.

If we use the phrase thanks for your support, we can't speak about its stability, although in general, expressions of gratitude have a high prevalence in the culture. However, it should be noted that in order to understand and use this phrase requires a limited level of competence in the English language. The only aspect that we can distinguish here is the internationality one.

This publication uses polylingual tools to demonstrate the use of various constructs for expressing gratitude emotions.

Consider the post dated August 9, 2019, which describes the process of preparing a new dish: "Po próbnych testach w ostatni weekend tego egzemplarza już nie trzeba jakoś szczególnie reklamować, ale $w$ ramach ciekawostki chcieliśmy tylko napomknąc, że wypalamy muszle w tao na żywym ogniu, grillujemy malże Swietego Jakuba z jednej strony, a następnie zalewamy sosem red nahm jim seafood \& olejem czosnkowym, et voila podajemy $w$ muszli $z$ micro kolendra i prażonym czosnkiem... Kicking ass scallops@molam_krk available from tonight, until the last shell stands."

("After last weekend's test trials, this sample doesn't need much publicity, but still, we only wanted to mention that we roast seashells in Tao over an open fire, then pour red Nam Jim sauce for seafood and garlic oil - and voila - serve in a seashell with micro herbs and fried garlic... Kicking ass scallops are available in Molam from tonight, until last shell stands")

To begin with, it is worth noting that the mention the name of the red nahm jim seafood sauce demonstrates the practicality aspect. 
Then we can again pay attention to the use of the French language element et voila. Today, we can say that this element has become very recognizable and familiar, has become accustomed to everyday speech and is used in many languages. However, its French component is still discernible, although in this case it is difficult to find an indication of any particular aspect of French culture associated with the phrase. In this context, it rather emphasizes the moment of dexterity and speed of the cooking.

The last sentence can be in general related to the international aspect. However, the nature of the chosen vocabulary should be noted. For example, kicking ass in the context of the last sentence is a very specific metaphor that corresponds to the colloquial style of speech, with a rough connotation, used to indicate the excellent quality of something. The use of this expression in speech makes it more youthful and slangy. It is possible to note that kicking ass may be perceived more as an Americanism. There are also a comic book series and a movie with a similar title ("Kick-Ass: The Dave Lizewski Years", 2008-2014; "Kick-Ass", 2010). Thus, both the aspect of recognition and the stereotype of the American version of English can be identified here.

Otherwise, when analyzing the last sentence of the publication, it should be noted that such words as available, tonight can be often found in blogs and on the websites of cafes and stores, which gives us the opportunity to relate them to the basic knowledge of English in the leisure and shopping theme.

It is interesting to analyze examples of publications where information is presented in both languages Polish and English.

To do this, consider the post, dated September 11, 2019: "SUMMERTIME we won't let you get away that easy, so we gonna bribe you to stay around for a little longer with our take on Thai mojito cocktail $\rightarrow>$ GECKO!

Rum Havana 3 na kościach lodu z puree $z$ truskawki i trawy cytrynowej [mmmm] sok $z$ limonki i mięta [fresh] woda $z$ kwiatów pomarańczy [extra fresh] i soda $z$ wody kokosowej [coco bubbles] + GEC-KO, GEC-KO! Do we have a deal?" (Rum Havana 3 with ice cubes and strawberry and lemongrass puree $[\mathrm{mmmm}]$, lime and mint juice [fresh], orange blossom water [extra fresh] and coconut water soda [coco bubbles] + GEC-KO, GEC-KO! Do we have a deal?)

One of the main features of the above is that the publication is narrated in two languages at once, and the information is not duplicated. In addition, the paragraph in Polish uses elements of English. The two languages become equivalent in the text. 
It is obvious that part of this publication, which includes the first paragraph of the text and the last sentence, is intended for readers who have competence in English above at least a sub-threshold level, as well as proficient in vocabulary that goes beyond the topics of cooking and gastronomy.

The Polish part of the post uses recognizable elements of English: words such as fresh, extra, coco, bubbles are actively used in advertising discourse, including food. These words somehow met even those who do not have any competence in English. It can be argued that such words are part of the foreign language linguistic landscape for consumers in different countries. Fresh, bubbles, in particular, are often used in the advertising description of refreshing drinks.

In many posts, we notice the "interweaving" of English and Polish, which allows us to judge that we are seeing the use of English not only as an international alternative to Polish for readers from other countries. It is obvious that the author of the blog thus use the opportunity to more fully convey the semantic shades, mood, emotions of the text part of the post through English.

This can also be seen when analyzing the post dated September 7, 2019.: “\#ONETEAM - WE ARE MOLAM!!

Team AM wine training session in progress... cause hardship never ends. $\mathrm{Nah}$, they have been really enjoying Riesling, erm.. life, like there is no tomorrow OTO ONI: młodzi, dzielni, piękni, mądrzy, zawsze uśmiechnięci - jedyni $w$ swoim rodzaju. Wszyscy razem, i co nie bez znaczenia, w porze śniadaniowej (to wymaga pełnego poświęcenia) zdobywaja wiedzę na temat win jednocześnie dzielac sie jedzeniem.

$<\ldots>$

Ty tez mozesz byc jak ONI - pić wina i dzielić się tajskimi daniami w towarzystwie pięknych, młodych, inteligentnych i zawsze uśmiechniętych... like there is no tomorrow!"

(“\#ONETEAM - WE ARE MOLAM!!

Team AM wine training session in progress... cause hardship never ends. Nah, they have been really enjoying Riesling, erm.. life, like there is no tomorrow

Here they are: young, bold, beautiful, smart, always with a smile — the only ones of their kind. Altogether, during Breakfast (this requires complete dedication), they gain knowledge about the wines and share the Breakfast.

$$
<\ldots>
$$


You can also be like them - drink wine and share Thai cuisine in the company of the beautiful, young, smart and always smiling... like there's no tomorrow")

The narration in this post uses the tools of English and Polish, while it does not duplicate information, but presents a coherent full-fledged text in two languages, although Polish makes up most of the post.

Based on the aspects we have highlighted, the English language in this case can be identified as internationalizing. In addition, we can highlight the recognition element associated with the expression like there is no tomorrow. It is fixed in the Cambridge online dictionary as a stable expression that means the desperation and recklessness in accordance with which a person performs any actions. In addition, the phrase is often found in the names of songs by popular artists, such as "Love me like there's no tomorrow" by Freddie Mercury and "Live like there's no tomorrow" by Selena Gomez. This increases the prevalence of this expression, since it has more opportunities to be fixed in the memory of a person who is interested in modern culture.

The use of this phrase in the Polish part of the text indicates its special status as a stable expression, which is recognizable even among those readers who do not have sufficient competence in English to understand the first part of the publication.

However, the blog also contains posts with duplicated information. For example, the post dated December 20, 2019: "We are only 5 days away from Xmas and it's FRI-YAY... we think it's time to officially start Festive Season at Molam NO W... 3... 2...1!

So, boys \& girls, let's go for tropical vibes tonight with eccentric Thai food \& J UN GL E B I R D S cocktail - the one to share with lovers \& friends (you already know we are crazy about sharing, right?) Dark Rum Havana 7 , Campari bitter, passionfruit puree, pineapple \& lime juice, juicy lychee, edible flower... teasing done!

Tylko 5 dni dzieli nas od Świąt, a tak sie składa, że dzisiaj jest w dodatku FRI-YAY... no i tak sobie myślimy, że to najlepszy moment aby oficjalnie rozpoczać sezon świątecznej zabawy juz dziś wieczorem... 3... 2...1!!! START

Rozpoczynamy wiec od totalnie tropikalnego koktajlu J UN G L E B I R D S $w$ wersji do podziału, bo jak już zapewne wiecie, mamy kompletnego świra na punkcie dzielenia się wszystkim! 
Dark Rum Havana 7, Campari bitter, puree z marakui, sok $z$ ananasa i limonki, soczyste liczi i kwiaty jadalne... no dobra, kuszenie jużzakończone!"

In this case, we see an example of a post containing a complete duplication of information in English and Polish, which in general can be defined as an international aspect.

We can also see the authenticity and practicality aspects in the names of Dark Rum Havana 7 and Campari bitter drinks. Naming them in this way allows the author to focus on the special status of these drinks, their price and quality. It is worth also noting the name of the cocktail - Jungle Birds. The English name has aspects of authenticity and internationality.

In addition, we can highlight the creative element contained in both parts of the post. FRI-YAY is a clear example of a language game that is understandable, including for readers with low English skills. The language game is formed by replacing part of the word Friday with an interjection expressing joy and enthusiasm - yay. Days of the week and interjections are very common entry-level vocabulary, which is probably why the author leave this game expression in the Polish part of the text. In addition, it helps to convey the light playful mood of the text.

In this publication, even if there is an equivalent duplication of text in two different languages, even a message aimed at a Polish reader contains an element of an English language game, which means that this element is considered decipherable for the average blog reader.

Thus, we have considered the language resource versatility is used in the "MOLÁM Thai Canteen \& Bar" blog. The elements used to create a versatile image of the bar. The role of the Thai language in publications can be clearly defined. It creates an image of professional workers who thoroughly know the details of Thai cuisine. The reader does not need to understand the words used in publications, since their primary purpose is to demonstrate an expert position. In addition, the author of the blog provide translation and explanation of the mentioned words.

The use of French in this blog has no serious culinary connotations. Here, using only well-established expressions, he additionally emphasizes emotional states, for example, pleasure, gratitude. Given the rare use in a blog, its role in creating a unique image is quite small, and can be understood as one of the facets that creates the image of a versatile person.

We find a more significant position of the English language. Here we find that English can serve as a tool designed to make it easier to point out 
certain ingredients. There are also ready-made expressions, and you can also note the vastness of the thematic vocabulary often used in advertising campaigns [Piller, 2001]. In addition, we observe a wide range of the English language associations: from youth slang to business expressions. This means that the language in this case is more sensitive to the context that forms the utterance and its interpretation.

Based on observations of this blog, we can conclude that the blog, as well as the restaurant itself, is aimed at a modern young reader who is highly educated, ready to be entertained and expand ones gastronomic experience [Kapkan, 2008]. In this case, we do not find any obvious claims to the elitism and sophistication of either the restaurant itself or its potential visitor.

\section{Conclusions}

After studying the materials of Instagram blogs, I come to the conclusion: multilingualism is a tool not only for communication, but also for identification. Thanks to it, we can see what language abilities the blog the author have and what kind of consumers a particular place is focused on, and what kind of readers the blog on Instagram is addressed to.

According to authoritative researchers such as Rampton, Jorgensen, Blommert, and Pennycook, multilingualism is a tool for communication in an open and multilingual, poly-ethnic and open environment, where communication languages are flexible and formed in the context of interaction. They can be considered as a language tool for establishing communication in the cosmopolitan environment of online blog readers. As a result, we can conclude something about the structure of multilingual communication in Instagram blogs that promote food industry establishments: this is the use of the native or/and the state language $(-s)$ of the host country, English as the language of the European Union, and the languages of cultures whose national cuisine is offered by a particular place.

Based on the case analysis, it is not possible to determine exactly which language is the native language of the blog the author, but we can assume that the native languages include Polish, Greek, and Ukrainian. In addition, we found out that the native languages of blog the author are not the only or dominant ones in Internet communication, they serve as location markers, establishing contact with a part of potential visitors.

Since for analysis were selected the blogs of food establishments located in the territory of the European Union and Eastern Europe, the second lan- 
guage of most of them, as we have seen, is English - the official language of the European Union, which is also one of the five world international communication languages.

English in these blogs performs not only the function of official attribution and unifying, as the language of international communication of the EU countries, but also as an ELF - a means of communication for people, whose native language is not English. And also as a language responsible for demonstrating western liberal culture stereotypes and cosmopolitanism international values. English is also present in the forms of mass culture texts, Internet memes, recognizable colloquial phrases and stable expressions.

We found that different blogs can broadcast different values of English culture and language: from British accuracy and foresight to American youth and protest emancipation, as well as with stereotypes: from British humor about British scientists to American slang. Moreover, quite often is implemented the "language game" based on the English language, common words and phrases.

In addition, regardless of the native and the English languages, gastronomic blogs can use the language of the cuisine that is offered by the restaurant, bar or cafe. Therefore, the Belgian institution actively uses Italian in its blog and the Polish institution uses Thai. In this case, the names of products, dishes, and characteristic elements of gastronomic culture are not translated, but are given in an authentic form of the name in the original language. This serves to form the emotional, value and cultural context of consumption, and to demonstrate the expert status of the institution in the field of a particular cuisine. This is how cultural realities and stereotypes are presented. For readers who do not speak these languages, an intrigue is created.

We also observed the use of the French language not only to demonstrate the stereotypes of Haute cuisine, but also to broadcast associations of French culture in a broader sense, as the birthplace of etiquette and ethics. There is an appeal to both precedent texts and recognizable phrases.

The role of the official languages, Polish (Krakow), Greek (Athens), Ukrainian (Lviv), French (Antwerp and Brussels) is that they are markers of the location of the institution on the map of Europe.

In the studied blogs, we observe the multilevel nature of polylinguism, the languages used in publications in different ways. The use of phrases in different languages also depends on the number and variety of linguistic resources that the author have. We identify the following levels of polylingualism demonstrated in the blogs we analyzed: factual, authentic, and pragmatic. 
Based on the materials studied, we can see how polylingualism is used to implement a strategy for combining the focus on attractiveness for local and international customers. Thus, it is possible to promote the food-serving institution more successfully in the service and leisure industry market.

A multi-lingual blog strategy allows creating a balance between cultures. It allows creating the content filled with multi-level meanings that can be encoded and decoded according to the blog author and reader's degree of education.

\section{Conflict of Interest}

The authors have no conflict of interest to declare.

\section{Acknowledgment(s)}

This research was financially supported by the Russian Foundation for Basic Research (Grant No. 17-29-09136\20 "Multilingualism in the Era of Post-literacy: Philosophical and Cultural Studies and Methodological and Pedagogical Development of a Multilingual Education Model").

\section{References:}

1. E. Cukerman. Novye soedineniya. Cifrovye kosmopolity v kommunikativnuyu epohu [New connections. Digital cosmopolitans in the communicative era]. Ad Marginem, Moscow (2015).

2. K. Shvab. Chetvertaya promyshlennaya revolyuciya [The Fourth Industrial Revolution]. - Eksmo, Moscow (2020).

3. The Blackwell guide to research methods in bilingualism and multilingualism. Ed. by Li Wei and Melissa Moyer. Blackwell, Oxford (2008).

4. CiPiaCe. https://www.instagram.com/cipiacebar/ (Accessed 17 March 2020).

5. Ferenc Hotel \& Restaurant. https://www.instagram.com/ferenc_hotel_restaurant/ (Accessed 01 April 2020).

6. MOLÁM Thai Canteen \& Bar. https://www.instagram.com/molam_krk/ (Accessed 28 March 2020).

7. Spondi_restaurant. https://www.instagram.com/spondi_restaurant/ (Accessed 21 March 2020).

8. M. V. Kapkan, L. S. Lihacheva. Gastronomicheskaya kul'tura: ponyatie, funkcii, faktory formirovaniya [Gastronomic culture: concept, functions, factors of formation]. Izvestiya Ural'skogo gosudarstvennogo universiteta. Ser. 2. Gumanitarnye nauki. [Bulletin of the Ural State University. Series 2. Humanities]. № 55. Issue 15 (2008), pp. 34-43. 
9. B. Rampton. Language Crossing and the Problematisation of Ethnicity and Socialisation. Pragmatics. № 5 (4) (1195). pp. 485-513.

10. J. N. Jørgensen. Polylanguaging in Superdiversity. Polylanguaging in Superdiversity. Diversities. № 13 (2) (2011), pp. 23-37.

11. J. Blommaert. Language and superdiversity. Diversities. № 3 (2) (2001). pp. 1-21.

12. A. Pennycook. Digital Metroliteracies: Space, Diversity and Identity. Handbook of Writing, Literacies, and Education in Digital Cultures. Routledge, London (2018). pp. 211-223.

DOI 10.15826/B978-5-7996-3081-2.24

\title{
Boundaries of Multimodality in Virtual Information Environment Design
}

\author{
Kalaykova Julia', Pankina Marina² \\ 1 Ural State University of Architecture and Art / Ural Federal University, \\ Ekaterinburg, Russia \\ 2 Ural Federal University, Ekaterinburg, Russia \\ Corresponding author: Pankina Marina, marina.pankina123@gmail.com
}

Abstract. Generating meanings through the use of various modes, simultaneous holistic multi-modal texts form the cognitive canvas of a virtual information environment. With reference to the current scientific discourse, we explore insights into the identification and interpretation of meanings in their multiplicity as a characteristic feature of objects of virtual information environment design and raise the question of human limits and potentialities in the perception of communicative images and the issue of communication in the virtual environment as a goal of design.

Keywords: multimodality, environment design, virtual information

\section{Introduction}

The growing computerization and virtualization of the information environment, particularly in the context of massive forced changeover to online 